\title{
A liberdade religiosa nas proposições de deputados evangélicos da Assembleia Legislativa do Estado do Paraná
}

\author{
Religious freedom in the propositions of evangelical \\ deputies of the Legislative Assembly of the State of Paraná
}

Cristina Satiê de Oliveira Pátaro ${ }^{1}$

Frank Antonio Mezzomo ${ }^{2}$

Daiana Nunes da Rosa ${ }^{3}$

Lucas Alves da Silva ${ }^{4}$

\section{Resumo}

Neste artigo, buscamos compreender a forma como os discursos sobre liberdade religiosa estão presentes nas proposições de quatro deputados evangélicos na Assembleia Legislativa do Estado do Paraná (ALEP). O corpus documental analisado é composto por oito matérias legislativas apresentadas pelos referidos deputados ao longo da 17ª legislatura (2015-2018). A seleção dos dados ocorreu a partir da tabulação de toda a produção legislativa, em que se observou a presença do discurso sobre a liberdade religiosa como forma de defesa de interesses oriundos do campo religioso. Os resultados apontam que a defesa dessa liberdade é acionada nos projetos e requerimentos, implicando na reivindicação de três pautas: (1) a não intervenção do Estado na atividade das Igrejas e na liberdade de crença; (2) o protagonismo da família ante a educação pública; (3) a liberdade religiosa em detrimento da liberdade de expressão. Os valores defendidos pelos deputados nas proposições analisadas se apresentam como conservadores no campo da moral, contra a discussão das questões de gênero e em defesa do poder da família sobre a educação, e utilizam o discurso da liberdade religiosa em detrimento da liberdade de expressão, desta forma, agem para defender os interesses de suas confissões religiosas.

1 Doutora em Educação pela Universidade de São Paulo (USP). Docente da Universidade Estadual do Paraná (UNESPAR), Câmpus de Campo Mourão.

2 Doutor em História Cultural pela Universidade Federal de Santa Catarina (UFSC). Docente da Universidade Estadual do Paraná (UNESPAR), Câmpus de Campo Mourão.

${ }^{3}$ Mestranda do Programa de Pós-Graduação Interdisciplinar Sociedade e Desenvolvimento da Universidade Estadual do Paraná, Câmpus de Campo Mourão (Bolsista CAPES).

${ }^{4}$ Mestrando do Programa de Pós-Graduação Interdisciplinar Sociedade e Desenvolvimento da Universidade Estadual do Paraná, Câmpus de Campo Mourão (Bolsista CAPES). 
Religare, ISSN: 19826605, v.15, n.2, dezembro de 2018, p.422-450.

Palavras-chave: liberdade religiosa; religião; produção legislativa.

\section{Abstract}

In this paper, we aim to understand how the discourses on religious freedom are present in the propositions of four evangelical deputies in the Legislative Assembly of the State of Paraná (ALEP). The documental corpus analyzed is composed of eight legislative matters submitted by said deputies during the 17th parliamentary term (2015-2018). The selection of the data occurred from the tabulation of the entire legislative production, in which the presence of the discourse on religious freedom was observed as a way of defending interests from the religious field. The results indicate that the defense of religious freedom is made use of in the bills and requirements, implying in the claim of three guidelines: (1) non-intervention of the State in religious activity; (2) the protagonism of the family before public education; (3) religious freedom to the detriment of freedom of speech. The values defended by the deputies in the proposals analyzed appear as conservatives in the field of morality, against the discussion of gender issues and in defense of family power over education, and use the discourse of religious freedom to the detriment of freedom of expression, therefore, act to defend the interests of their religious denominations.

Keywords: religious freedom; religion; legislative production.

\section{Introdução}

Após um longo período marcado historicamente pela hegemonia católica no Brasil, as últimas três décadas têm demonstrado que outras forças religiosas se fazem presentes e atuantes na esfera política. Com a queda das cortinas que separavam evangélicos e a política partidária, ainda na década de 1980, instaurou-se uma nova configuração no cenário político que, entre outras mudanças, introduziu na cultura pública do país novas formas de sociabilidades, tangenciadas, nesse caso, pela participação evangélica. A presença evangélica nesse espaço, aqui entendido como aquele lugar constituído por fluxos discursivos que geram formas de visibilidade 
Religare, ISSN: 19826605, v.15, n.2, dezembro de 2018, p.422-450.

(MONTERO, 2012), tem consequências nas dinâmicas de disputas por poder e na busca por legitimidade social.

Uma das marcas deste movimento de emergência evangélica pode ser evidenciada nos canais midiáticos brasileiros, que passaram a ser utilizados como forma de propagação de crenças e conquistas de fiéis por todos os cantos do país, caracterizando disputas próprias do mercado religioso que passou a formar (PIERUCCI, 2012). Outras formas de alcançar visibilidade na cena pública são as modificações na paisagem urbana (MIRANDA, 2013) e a participação na política, especialmente nos legislativos, seja municipal, estadual ou nacional (CARRANZA, 2017; ALMEIDA, 2017b).

No que se refere à participação política, tem sido prática comum entre os parlamentares que possuem vinculação religiosa evangélica defender agendas que buscam direta ou indiretamente dar visibilidade ao grupo religioso ao qual pertencem. Paralelamente a esta tentativa evidente de se fazerem presentes na cultura, no cotidiano e na política, “há questionamentos sobre a própria legalidade, sobre os arranjos político institucionais e jurídicos, que abrigam essa presença religiosa" (BURITY, 2015, p. 94). Estes embates ocorrem principalmente quando se coloca em pauta o ideal republicano de laicidade estatal, que, segundo Mariano (2011), trata da emancipação do Estado de toda influência e legitimação religiosa. A maior parte das controvérsias se dão em relação ao comportamento de legisladores que atuam para favorecer interesses confessionais (MACHADO, 2017; ALMEIDA, 2017a).

Em meio a tais embates, observa-se que o crescimento demográfico dos evangélicos é expressivo. Segundo dados do IBGE (2010), o grupo no Brasil com uma miríade de denominações - compõe uma minoria considerável, totalizando 22,2\% frente aos $64,6 \%$ católicos. Já no Paraná, os evangélicos representam 22,2\% diante $69,9 \%$ de católicos. Perante tal magnitude 
Religare, ISSN: 19826605, v.15, n.2, dezembro de 2018, p.422-450.

demográfica, há esforços para aumentar o grau de influência nos itinerários sociais, sendo a política um dos principais espaços utilizados pelos evangélicos para se fazerem presentes na vida pública do país. Em meio a este empreendimento, a discussão sobre liberdade religiosa tem sido uma das pautas recorrentes.

A presença evangélica na política complexifica as demandas em torno da questão da laicidade e do direito à liberdade religiosa, ambos princípios constituídos na modernidade ocidental. Esse debate tende a ocorrer em contextos de pluralização religiosa, ou seja, naqueles em que uma religião tradicionalmente hegemônica perde espaço e a discussão se estabelece perante a busca de liberdade individual para crer e de liberdade para religiões minoritárias também atuarem publicamente (HERVIEU-LÉGER, 2015). Vale destacar, ainda conforme Hervieu-Léger (2015, p. 187), que a laicidade republicana não se opõe à religião, "mas à tutela clerical que a instituição religiosa entendia fazer pesar sobre o poder público". Desta forma, ao mesmo tempo em que, no contexto do Estado laico, as religiões são juridicamente separadas do cenário político, abre-se espaço, por meio da defesa da liberdade religiosa, para sua livre atuação e articulação junto à sociedade civil (MONTERO, 2006).

No entendimento de Emerson Giumbelli (2014), e oportuno para nossa discussão, o catolicismo foi assimilado como a "religião natural" no Brasil, e desse modo reverenciado publicamente. Essa ampla legitimidade tornou possível que o catolicismo fosse colocado e aceito como expressão da cultura nacional. Contudo, na esteira da redemocratização ocorrida na década de 1980, passamos a visualizar o processo de minoritização que possibilitou o surgimento público e estruturação política de igrejas e outros grupos que até então se encontravam mais às margens das disputas de poder (BURITY, 2016). Dessa forma, os evangélicos estão inseridos nessa conjuntura como uma 
Religare, ISSN: 19826605, v.15, n.2, dezembro de 2018, p.422-450.

expressão social que vem se firmando, não se colocando como parte de uma "cultura nacional", ou "cultura étnica"5, mas como "cultura pública", que atua vislumbrando o futuro (GIUMBELLI, 2014).

Nesse cenário, os grupos religiosos usufruem de dispositivos garantidores de que no âmbito público, em uma sociedade democrática, o direito à liberdade é garantido por lei, desde que tais práticas não transgridam a ordem pública e atuem positivamente na garantia dos valores e regras almejados pelo Estado (HERVIEU-LÉGER, 2015). Isso implica na aceitação, pelas diferentes agremiações religiosas, de um conjunto de nor mas que devem ser respeitadas ao acionar o direito à liberdade religiosa. Com isso, os grupos que se pretendem fazer presentes no cenário político devem adequar suas práticas e seus discursos às regras que regem a sociedade e estão presentes na Constituição, sob o risco de sofrer a intervenção de dispositivos estatais, que visam garantir o cumprimento das leis.

Diante do contexto apresentado, e levando em consideração o fato de que existem diversas formas de se estabelecerem articulações entre o Estado e a religiões (CAMURÇA, 2017), buscamos entender de que forma os discursos sobre a liberdade religiosa são acionados nas proposições ${ }^{6}$ apresentadas por deputados evangélicos na Assembleia Legislativa do Estado do Paraná (ALEP). Acompanhamos, assim, desde a campanha eleitoral de 2014, os Deputados Pastor Edson Praczyk - vinculado à Igreja Universal do Reino de Deus e filiado ao Partido Republicano Brasileiro, Cantora Mara Lima - vinculada à Igreja Assembleia de Deus e filiada ao Partido Social Cristão, Gilson de Souza - vinculado à Igreja do Evangelho Quadrangular e filiado ao

\footnotetext{
5 A caracterização como "cultura étnica" é usada pelas religiões de matriz afro-brasileira (GIUMBELLI, 2014).

${ }^{6}$ Segundo o regimento da ALEP, no artigo 157: "Proposição é toda matéria sujeita à deliberação da Assembleia, que será recebida pela Mesa, numerada, datada, despachada às Comissões competentes e publicada no Diário Oficial ou no site da Assembleia Legislativa, para consulta pública" (PARANÁ, 2016).
} 
Religare, ISSN: 19826605, v.15, n.2, dezembro de 2018, p.422-450.

Partido Social Cristão, e por último, Missionário Ricardo Arruda - vinculado à Igreja Mundial do Poder de Deus e filiado atualmente ao Partido Social Liberal, e, no presente artigo, procuramos problematizar algumas produções legislativas apresentadas na ALEP ao longo de seus mandatos, entre 2015 e 2018. Esses parlamentares foram categorizados como religiosos políticos, ou seja, como sujeitos que detêm um vínculo religioso explícito anterior à sua eleição e que é mantido ao longo do mandato enquanto deputados (CARVALHO JUNIOR; ORO, 2017).

Como material empírico, analisamos seis projetos de lei e dois requerimentos de autoria dos referidos deputados, os quais estão disponíveis para consulta online no site da ALEP7. Nesse horizonte, interpretamos os movimentos dos evangélicos no parlamento estadual como articulado com o que ocorre no cenário político nacional, pois não parecem estar isolados de outras ações desenvolvidas, por exemplo, pela Bancada Evangélica no Congresso Nacional (CUNHA; LOPES; LUI, 2017). Vale ter presente que as ações dos parlamentares paranaenses estão vinculadas, com diferentes graus de comprometimento, com o seu campo de origem, ou seja, com as igrejas evangélicas às quais estão ligados, bem como os seus esforços para se fazerem visíveis, executar suas pautas e trazer para esfera política visões de mundo das quais compartilham.

Os quatro deputados religiosos apresentam características que se assemelham aos comportamentos dos parlamentares federais que, já na década de 1980, colocaram-se militando pela liberdade religiosa na política partidária, com medo de que o hegemônico catolicismo se tornasse a religião

\footnotetext{
${ }^{7}$ Esta pesquisa faz parte do projeto "Evangélicos na Assembleia Legislativa do Estado do Paraná: análises das articulações entre religião e política nos mandatos de deputados estaduais" do Grupo de Pesquisa Cultura e Relações de Poder da Universidade Estadual do Paraná, Câmpus de Campo Mourão no qual examinamos toda a produção legislativa entre 2015 e 2017 de deputados evangélicos.
} 
Religare, ISSN: 19826605, v.15, n.2, dezembro de 2018, p.422-450.

oficial novamente, ou mesmo de que um comunismo ateísta tomasse o Estado (BURITY, 2018). Essas preocupações foram traduzidas para uma disputa política com revestimento de batalha espiritual no discurso de líderes religiosos, particularmente os evangélicos. Como veremos na sequência, na análise de parte das proposições apresentadas pelos referidos deputados religiosos, essa pauta parece persistir no cenário político, embora que ressignificado e atualizado às demandas contemporâneas.

\section{Analisando as proposições sobre liberdade religiosa}

Identificamos oito proposições - seis projetos de lei e dois requerimentos - que foram apresentadas pelos políticos religiosos ao longo de seus mandatos, 2015 a 2018, e que pautam a problemática da liberdade religiosa. Como veremos, elas expressam, por diferentes vieses e interpretação, como a liberdade vem sendo pautada pelos evangélicos na ALEP.

A primeira proposição foi apresentada em 2015 pela Deputada Cantora Mara Lima, e procura instituir a Política Estadual da Liberdade Religiosa (Projeto de Lei n. 676/2015) pelo combate à intolerância, discriminação e desigualdade de caráter religioso ${ }^{8}$. Os tópicos da proposta tratam dos princípios constitucionais que asseguram a liberdade religiosa, dos direitos individuais

\footnotetext{
${ }^{8}$ A política de liberdade religiosa não é uma inovação paranaense. O Rio de Janeiro foi o primeiro estado brasileiro a implementar um Plano Estadual de Promoção da Liberdade Religiosa, de caráter inter-religioso, em janeiro de 2018. Informações disponíveis em: $<$ http://agenciabrasil.ebc.com.br/geral/noticia/2018-01/rio-e-primeiro-estado-ter-plano-econselho-de-promocao-da-liberdade-religiosa $>$. Acesso em: 03 out. 2018. Também tramita, na Assembleia Legislativa do Estado do Rio de Janeiro, o Estatuto Estadual da Igualdade Religiosa, proposto pelo umbandista Deputado Átila Nunes, que também foi promovedor do Plano Estadual de Promoção da Liberdade Religiosa na sua gestão como Secretário de Estado do Rio de Janeiro (2017-2018). No âmbito nacional, foi instituído o Dia Nacional de Combate à Intolerância Religiosa (Lei n. 11.635/2007) durante a gestão de Gilberto Gil no Ministério da Cultura. A data, fixada em 21 de janeiro, rememora o falecimento da Iyalorixá Mãe Gilda, vítima de intolerância religiosa (CAMURÇA, 2017).
} 
Religare, ISSN: 19826605, v.15, n.2, dezembro de 2018, p.422-450.

de liberdade de crença, como por exemplo, de objeção de consciência ${ }^{9}$, dos direitos coletivos entendidos como licença para organização institucional e da garantia para ministros de confissão religiosa exercerem seu ministério na esfera pública ou privada. Por fim, coloca as violações à liberdade religiosa e as sanções previstas para esses atos. Além do projeto de lei, a Cantora Mara Lima apresentou uma segunda proposição solicitando a realização de audiência pública com o tema Liberdade Religiosa na ALEP (Requerimento n. 6620/2017).

Quanto ao trâmite, o projeto da Política Estadual da Liberdade Religiosa recebeu parecer contrário do relator Deputado Tiago Amaral (Partido Socialista Brasileiro), na Comissão Constituição Justiça (CCJ), sob o argumento de que a objeção de consciência poderia ser alegada como dispensa ao serviço militar, ao qual todo brasileiro do sexo masculino é obrigado. A Deputada, por sua vez, apresentou recurso da decisão e a proposta continua em análise com um novo relator.

A audiência pública solicitada pela Cantora Mara Lima foi realizada em 21 de novembro de 2017, quando participaram representantes da comunidade israelita, da Associação Inter-Religiosa de Educação, do Instituto Brasileiro de Estudos Islâmicos, da Federação Umbandista do Paraná, do Centro de Estudos Budista Bodisatva e também de José Aparecido, capelão da ALEP e representante, na ocasião, do arcebispo de Curitiba, Dom José Antônio Peruzzo. De modo geral, os convidados se manifestaram favoráveis

\footnotetext{
${ }^{9} \mathrm{O}$ texto do projeto de lei declara que a garantia quanto a objeção de consciência se efetiva pelo direito ao não"cumprimento de leis que contrariem os ditames impreteríveis da própria consciência, dentro dos limites dos direitos e deveres impostos pela Constituição" (Projeto de Lei n. $676 / 2017$, art. 13).
} 
Religare, ISSN: 19826605, v.15, n.2, dezembro de 2018, p.422-450.

ao projeto, especialmente o umbandista Edward James Santos Harrison, que relatou as hostilidades sofridas por sua comunidade ${ }^{10}$.

A terceira proposição, também projeto da Deputada Cantora Mara Lima, propõe a criação do Dia de Proclamação do Evangelho no Calendário Oficial de Eventos do Estado como "mais uma forma de reconhecimento da importância da Palavra de Deus para a sociedade e mais uma oportunidade de propagação da mensagem de amor e salvação da cruz de Jesus Cristo, sem ferir a liberdade religiosa de cada indivíduo" (Projeto de Lei n. 675/2017). Esse projeto faz parte de uma série de movimentos que os deputados evangélicos realizaram para comemorar os 500 anos da Reforma Protestante na ALEP.

O quarto projeto trata do Programa Escola Sem Partido ${ }^{11}$, apresentado pelo Deputado Missionário Ricardo Arruda (Projeto de Lei n. 606/2016), e que pretende implantar o Programa Escola Sem Partido nas instituições de ensino do Paraná. Para isto, propõe a afixação em todas as salas de aulas de um cartaz com os deveres do professor ${ }^{12}$. A iniciativa, já aprovada na CCJ da

10 Informações no site da ALEP, disponível em: <http://www.alep.pr.gov.br/ divulgacao/noticias/audiencia-publica-na-assembleia-legislativa-debate-tema-da-liberdadereligiosa> Acesso em: 03 out. 2018.

11 O projeto de implantação do Programa Escola Sem Partido tem como coautor o Deputado Felipe Francischini (PSL) - outro projeto semelhante havia sido proposto e arquivado em 2015, este contava com a coautoria de diversos parlamentares, entre os quais os quatro deputados evangélicos (Projeto de Lei n. 748/2015). Entre os dois projetos, há apenas alterações formais na justificativa, mas os artigos de lei são os mesmos.

${ }^{12} \mathrm{O}$ cartaz apresenta os seguintes deveres: "1. O professor não se aproveitará da audiência cativa dos alunos para promover os seus próprios interesses, opiniões, concepções ou preferências ideológicas, religiosas, morais, políticas e partidárias; 2. O professor não favorecerá, nem prejudicará os alunos em razão de suas convicções políticas, ideológicas, morais ou religiosas, ou a falta delas; 3 . O professor não fará propaganda político partidária em sala de aula nem incitará seus alunos a participar de manifestações, atos públicos e passeatas; 4 . Ao tratar de questões políticas, socioculturais e econômicas, o professor apresentará aos alunos de forma justa - isto é, com a mesma profundidade e seriedade, - as principais versões, teorias, opiniões e perspectivas concorrentes a respeito; 5 . O professor respeitará o direito dos pais a que seus filhos recebam a educação moral que esteja de acordo com suas próprias convicções; 6 . O professor não permitirá que os direitos assegurados aos itens anteriores sejam violados pela ação de terceiros dentro de sala de aula" (Projeto de Lei n. 606/2016). 
Religare, ISSN: 19826605, v.15, n.2, dezembro de 2018, p.422-450.

casa $^{13}$, faz parte de um movimento nacional que busca, segundo seus proponentes, "dar visibilidade a um problema gravíssimo que atinge a imensa maioria das escolas e universidades brasileiras: a instrumentalização do ensino para fins políticos, ideológicos e partidários" (ESCOLA SEM PARTIDO, 2018, online).

Ainda no que tange à educação, observamos a quinta proposição, um pedido de envio de informações ao Secretário de Estado da Educação, Fernando Xavier Ferreira, acerca do Plano Estadual de Educação. O requerimento foi apresentado em 23 de abril 2015, semanas antes de o Plano ser enviado para a ALEP, em maio do mesmo ano, portanto quando ainda estava em vias de elaboração pelo Poder Executivo. Deputado Gilson de Souza questionou sobre o que o plano previa quanto à diversidade sexual nas escolas, com vistas a indagar acerca de quais os grupos que participariam dessa discussão, de interesse da família paranaense, da qual ele se colocava como um representante (Requerimento n. 1920/2015).

A sexta matéria foi proposta no ano de 2016 pelo Deputado Pastor Edson Praczyk, e trata da Imunidade tributária para templos religiosos, direito já garantido na Constituição Federal. Considerando a dificuldade de as igrejas obterem, de modo célere, alvarás de funcionamento em nível municipal, documento necessário para solicitar a isenção fiscal, o projeto centrado na isenção do ICMS - Imposto sobre Circulação de Mercadorias e Serviços -, propõe que outros documentos sejam aceitos para que os templos possam solicitar a isenção fiscal, tais como: Ata de Eleição da atual Diretoria, Estatuto Social e CNPJ (Projeto de Lei n. 11/2016, art. 2). A matéria, em tramitação, já recebeu parecer favorável da CCJ e da Comissão de Finanças da ALEP.

13 A íntegra da sessão de discussão do projeto na CCJ está disponível em: $<$ https://www.youtube.com/watch?v=a3ZcaFRB00k>. Acesso em: 03 out. 2018. 
Religare, ISSN: 19826605, v.15, n.2, dezembro de 2018, p.422-450.

O quinto projeto foi apresentado pelo Deputado Missionário Ricardo Arruda em 2017, e estabelece Limites para emissão sonora nas atividades em templos religiosos pelo regramento do volume de decibéis permitidos de acordo com o horário e a área da cidade. Segundo justificativa, "as atividades religiosas não se desenvolvem ininterruptamente, o que mostra como o critério hoje utilizado por alguns Municípios, além de ilegítimo e inadequado, pode ser considerado também draconiano" (Projeto de Lei n. 305/2017, p. 3), porque inviabiliza a expressão religiosa ${ }^{14}$.

A oitava proposição, um requerimento submetido em 2017, solicita a aprovação da moção de repúdio aos produtores da peça teatral Pornô Gospel, que foi endossado pelos quatro deputados evangélicos. $\mathrm{O}$ espetáculo era protagonizado pelos personagens pastor Jair Malagaia, empresário da cantora gospel Nara Lira, fazendo referência ao Pastor Silas Malafaia ${ }^{15}$ e à Deputada Cantora Mara Lima. Os parlamentares consideram a manifestação artística ofensiva, intolerante, discriminatória, constrangedora, vexatória e uma prática de violência simbólica e, nesse sentido, encaminharam o requerimento em prol do que consideram liberdade religiosa (Requerimento n. 3.024/2016). Repercutindo a iniciativa parlamentar, o principal jornal do Paraná, a Gazeta do Povo, publicou em 31 de maio de 2016 que a trama da peça se passava "durante uma eleição em que vários religiosos com atuação na mídia são candidatos" (MOSER, 2016). O portal eletrônico Gospel Prime afirmou que a peça satirizava a forma "como líderes de igrejas utilizam a fé para tirar dinheiro dos fiéis ou conseguir promoção própria" (ARAGÃO, 2016). Nesse controverso contexto, Mariana Zanette (diretora da peça) e Ludmila Nascarella (produtora e atriz) protestaram contra a censura, pela

\footnotetext{
${ }^{14}$ A proposta tramita na CCJ desde 28 de julho de 2017.

${ }^{15}$ Silas Malafaia é pastor da Assembléia de Deus, Ministério Vitória em Cristo. Coloca-se como uma das principais lideranças evangélicas do país tendo intensa presença midiática e protagonismo no combate aos movimentos feministas e LGBTs (VITAL; LOPES, 2012).
} 
Religare, ISSN: 19826605, v.15, n.2, dezembro de 2018, p.422-450.

liberdade de expressão artística e pelo direito de criticar a sociedade ${ }^{16}$.

Segundo os produtores, a peça objetivou gerar uma reflexão no público adulto e usar o teatro como ferramenta transformadora e desalienadora, de combate ao ódio e à intolerância religiosa por meio do fomento ao respeito com o diferente.

A partir do exame das oito proposições, identificamos três linhas argumentativas que ajudam a entender como os deputados evangélicos articulam a questão da liberdade religiosa nas matérias legislativas, reivindicando como um direito religioso inalienável, nesse caso acionado a partir da perspectiva do universo evangélico.

\subsection{A liberdade pela não intervenção do Estado nas atividades religiosas}

Os argumentos basilares para defender a livre manifestação religiosa nas proposições partem do princípio legal que assegura a liberdade religiosa e, portanto, os políticos religiosos recorrem ao texto da Constituição Federal de 1988 que, em seu artigo 5º, inciso VI, estipula: “é inviolável a liberdade de consciência e de crença, sendo assegurado o livre exercício dos cultos religiosos e garantida, na forma da lei, a proteção aos locais de culto e as suas liturgias" (BRASIL, 2018, p. 17).

Para a Cantora Mara Lima, “todos os indivíduos, grupos religiosos e o Poder Público devem reconhecer a diversidade de religiões presentes no território paranaense dentro de um espírito de tolerância mútua e compreensão, sendo respeitados o proselitismo e o discurso exclusivista não violento" (Projeto de Lei n. 676/2015, art. 5). Por conseguinte, afirma os direitos coletivos de liberdade religiosa, tais como: a criação e o

16 Declarações disponíveis em: <https://www.youtube.com/watch?v=OeQll6dgglE>, e em: $<$ https://www.youtube.com/watch?v=ejCZgQqEqH4>. Acesso em: 03out. 2018. 
Religare, ISSN: 19826605, v.15, n.2, dezembro de 2018, p.422-450.

funcionamento das organizações religiosas, o ensino e difusão da doutrina, o recebimento de contribuições, as parcerias com o poder público, a criação e manutenção de escolas e a promoção de expressões culturais. Assim, entendemos que o foco é garantir o livre direito à organização administrativa religiosa como forma de manter e fortalecer a estrutura já existente nas instituições, e também de propagar as crenças religiosas, tanto por meio da educação como por vias culturais sem cerceamentos ou intervenções estatais, pois “a liberdade religiosa só admite as restrições necessárias para salvaguardar direitos" (Projeto de Lei n. 676/2015, art. 6).

A mesma deputada sustenta o direito individual quanto à objeção de

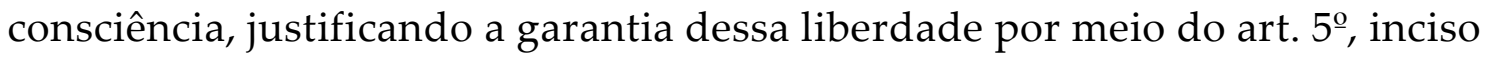
VIII da Constituição Federal, que dispõe: "ninguém será privado de direitos por motivo de crença religiosa ou de convicção filosófica ou política, salvo se as invocar para eximir-se de obrigação legal a todos imposta e recusar-se a cumprir prestação alternativa" (BRASIL, 2018, p. 17).

A liberdade religiosa, colocada como um dos pilares da modernidade tem os princípios das liberdades de crença e de culto garantidos nas constituições republicanas ao redor do mundo como um direito fundamental. Para tornar mais claras as discussões em torno da liberdade religiosa, tratamos da diferenciação entre liberdade de crença e de culto. $\mathrm{O}$ primeiro caso refere-se à liberdade de escolha da religião ou seita, assim como o direito de mudar de religião, bem como de ser ateu ou agnóstico. Já a liberdade de culto aponta para a livre manifestação da crença, do direito de cada indivíduo expressar e praticar sua religião, tanto nos templos como no cotidiano (LEITE, 2012).

Com base nesta compreensão, percebemos que a liberdade de crença, por estar mais relacionada à manifestação individual e subjetiva, é ilimitada, já a liberdade de culto está sujeita a limitações, por tratar-se de práticas 
Religare, ISSN: 19826605, v.15, n.2, dezembro de 2018, p.422-450.

realizadas em âmbito público, regido por regras sociais e jurídicas. A liberdade religiosa garantida na Constituição brasileira, "interpretada à luz dos princípios fundamentais da dignidade da pessoa humana, da cidadania e do pluralismo religioso" (LEITE, 2014, p. 306), defende o direito aos cidadãos para que "seja verificada a possibilidade de se conferir tratamentos excepcionais, em casos específicos, àqueles cidadãos que se encontram impedidos de exercer a sua religião por força de normas emanadas do Estado" (LEITE, 2014, p. 306). Desta forma, é garantido que tais situações sejam levadas para análise, ou seja, o direito de cada indivíduo em recorrer ao âmbito jurídico. Nesse sentido, Leite afirma que “a liberdade de crença é o direito de exprimir uma crença e não o de ter uma crença" (2014, p. 313), caso contrário não haveria necessidade da tutela e garantia estabelecida por lei.

Embora a Constituição garanta os direitos ao cidadão independentemente da sua crença, não dá garantia de que as leis considerarão em todas as situações a doutrina religiosa da qual ele professa (LEITE, 2012). Assim, o projeto de lei estadual busca resolver o problema jurídico que as diferentes interpretações do texto da Constituição podem gerar. A deputada especifica que "na realização de concursos públicos e vestibulares, deve-se observar as datas que não levantem objeções ao repouso sagrado" (Projeto de Lei n. 676/2015, art. 15). Nesse sentido, a proposta visa reforçar o direito à liberdade religiosa por meio da objeção de consciência de um indivíduo, a ponto de se negar a cumprir determinados deveres por conta das crenças, e faz com que as instituições se adequem às crenças religiosas.

Ao tratar da laicidade, Cantora Mara Lima alega a não intervenção do Estado nas organizações religiosas e a não adoção preferencial de qualquer religião. Desse modo, o poder público não pode “obstaculizar, por qualquer meio, o regular exercício da fé religiosa dentro dos limites em Lei" (Projeto 
Religare, ISSN: 19826605, v.15, n.2, dezembro de 2018, p.422-450.

de Lei n. 676/2015, art. 9). Além disso, o Estado deve proteger e salvaguardar, quanto ao respeito público, as seguintes manifestações culturais: "I - a presença de símbolos religiosos ou livros sagrados em prédios pertencentes à administração Pública Direta e Indireta. II - a exposição de mensagem de cunho religioso em solenidades oficiais. III - a existência de feriados dedicados a ícones religiosos" (Projeto de Lei n. 676/2015, art. 24).

Em meio à discussão quanto aos limites do Estado diante da liberdade religiosa, percebemos a busca de garantia para liberdade de expressão da crença religiosa e por uma forma de se fazer presente em ambientes públicos, fato já observado em outros locais públicos, como em escolas, universidade, hospitais, aeroportos, tribunais de justiça, câmaras legislativas, entre outros espaços (GIUMBELLI, 2013; RANQUETAT JÚNIOR, 2012). Há, por parte dos evangélicos, uma disposição para não entrar em conflito direto com os católicos, uma vez que estes detêm maior presença pública devido a sua histórica relação com o Estado brasileiro desde a chegada dos portugueses nestas terras. Ao evitar o confronto direto com católicos, os evangélicos buscam garantir os mesmos espaços e direitos da primeira às religiões que não possuem a mesma tradição na cultura do país.

O projeto da liberdade religiosa também trata do direito de ministros de confissão religiosa exercerem seu ministério na esfera pública ou privada com livre acesso e sem coação, tais como: "presidir com liberdade as cerimônias, [...] admitir ou excluir membros da comunidade [...], dirigir e presidir atividade de proselitismo, assistência social, beneficência e outras atividades públicas" (Projeto de Lei 676/2015, art. 27). Vale ressaltar que, na ALEP, é frequente a realização de cultos de ação de graças e de grupos de oração, seja católico ou evangélico, com a ministração dos ritos tanto pelos políticos religiosos, com por autoridades eclesiásticas. 
Religare, ISSN: 19826605, v.15, n.2, dezembro de 2018, p.422-450.

Na mesma linha argumentativa, observamos a proposição do Dia Estadual de Proclamação do Evangelho ${ }^{17}$, na qual ressalva que a celebração não fere a liberdade religiosa individual ao colocar como objetivo, dar "ampla divulgação à proclamação do Evangelho sem qualquer discriminação de credo dentro das igrejas cristãs do Paraná" (Projeto de Lei n. 675/2017, art. 2). A data escolhida, 31 de outubro, é mundialmente conhecida como o "Dia das Bruxas" ou "Halloween", antecedendo à comemoração católica do Dia de Todos os Santos em 1 de novembro. Os deputados evangélicos do Paraná, aproveitando a comemoração dos 500 anos da Reforma Protestante, recorrem à tradição para tornar essa comemoração conhecida como a data em que “Martinho Lutero, afixou na porta da igreja de Wittemberg, na Alemanha, 95 teses contrárias a diversos pontos da doutrina da Igreja Católica Romana"18 (Projeto de Lei n. 675/2017).

Pastor Edson Praczyk, quanto ao ICMS, também se fundamenta na Constituição Federal de 1988 que, no artigo 150, inciso VI, proíbe “instituir impostos sobre [...] templos de qualquer culto" (BRASIL, 2018, p. 124). Apesar de o texto constitucional referir-se especificamente aos templos, a lei é aplicada generosamente para beneficiar as igrejas, isto é, a entidade

\footnotetext{
${ }^{17}$ Em 12 de janeiro de 2016, a ex-presidente Dilma Rousseff sancionou a Lei n. 13.246 que instituiu 31 de outubro como Dia Nacional da Proclamação do Evangelho. A comemoração nacional é fruto do projeto de lei 2828/2003 de autoria do Deputado Neucimar Fraga (PL/ES). Os artigos do projeto estadual, embora não faça menção, são uma cópia do projeto federal, acrescentando a justificativa da comemoração dos 500 anos da Reforma Protestante.

${ }^{18}$ Também foi instituído, por iniciativa do Deputado Gilson de Souza, o dia 31 de outubro como o Dia da Reforma Protestante (Projeto de Lei n. 429/2016). O deputado destacou que esta homenagem não é apenas uma questão religiosa, isso porque, segundo ele, a Reforma Protestante trouxe avanços também na educação, na economia, na cultura e na política. A motivação para a criação da lei, segundo o deputado evangélico, surgiu a partir de uma visita de pastores luteranos que discutiam as comemorações dos 500 anos de história da reforma. Segundo Gilson de Souza: "muitos comemoram o Halloween, uma data, uma festa que nada tem a ver conosco, mas o Dia da Reforma Protestante tem tudo a ver conosco, então, graças a Deus, eu vou poder ser esse instrumento para proporcionar esse momento tão especial" (sic). Declarações disponíveis em: $<\mathrm{https}: / / \mathrm{www}$.youtube.com/watch? $\mathrm{v}=\mathrm{uFYSQWB} 4 \mathrm{spg} \&$ feature=+youtu.be\&t=3m48s $>$. Acesso em 10 out. 2018.
} 
Religare, ISSN: 19826605, v.15, n.2, dezembro de 2018, p.422-450.

mantenedora do templo (CARVALHO, 2011). Juridicamente, interpreta-se como templo o "local aonde é desenvolvido o culto e os bens necessários ao desenvolvimento deste" (SILVA, 2002, p. 73). Apesar desse caráter abrangente da lei, cultos de minorias, como os das religiões de matriz africana, sofrem um silenciamento nas decisões dos órgãos superiores do judiciário, pois estes tendem a privilegiar católicos e evangélicos: “isso se dá, em grande medida, pelo próprio uso de uma doutrina jurídica que é omissa ao tratar dessa questão" (NASCIMENTO; DUARTE; QUEIROZ, 2017, p. 1170).

O projeto de lei do pastor reforça a interpretação majoritária de que a imunidade tributária deva ser aplicada às organizações religiosas, ou seja, para as religiões na sua forma institucionalizada, posto que "o benefício não é dirigido a qualquer edificação onde se praticam cultos, mas somente àquelas que pertençam a organizações religiosas [...]. Somente quando digam respeito a pessoas jurídicas é que estarão livres do poder impositivo tributário" (CRESPI; KEMPFER, 2013, p. 101-102). Portanto, observa-se de modo reiterado a utilização do poder do Estado, desta vez o de isentar a tributação, em favor da liberdade religiosa.

De modo paralelo, observamos a mesma questão no projeto de lei n. 305/2017, que busca estabelecer limites para emissão sonora nas atividades em templos religiosos no Paraná. Apesar de entender como "necessária a legítima arbitragem do Poder Legislativo" (Projeto de Lei n. 305/2017), o projeto busca restringir a autonomia dos municípios para criarem legislações, declarando o caráter “draconiano" das regras locais. Desse modo, o Deputado age como um representante dos interesses das organizações religiosas, que estariam acima das motivações e particularidades de cada município. A utilização de instrumentos, tais como microfones e caixas de som, é central nas práticas religiosas modernas, especialmente nos cultos pentecostais, nos 
Religare, ISSN: 19826605, v.15, n.2, dezembro de 2018, p.422-450.

quais o som é utilizado como meio sensorial de se experienciar o Espírito Santo. Nesses ambientes "as mídias são autenticadas como parte inextricável do próprio transcendental que é alvo de - e, a partir de uma perspectiva de fora: invocada pela - mediação" (MEYER, 2015, p. 154). Daí a regulamentação sobre a emissão sonora ser de interesse do Deputado missionário que, ao mesmo tempo que regula, garante o direito de continuidade de tais práticas.

O ânimo para garantir a liberdade religiosa faz com que, entre tantas atividades que causam emissão sonora com potencial de poluição urbana, surja a disposição parlamentar de criar uma legislação estadual específica e diferenciada para as organizações religiosas, retirando, portanto, do âmbito municipal a autodeterminação para regulamentar a emissão desses ruídos (TERAOKA, 2010). O projeto demonstra que a liberdade de culto, conceito já definido anteriormente, deve respeitar o conjunto de regras que regem o funcionamento da ordem pública (LEITE, 2012), mas considera essa liberdade mais importante que as questões municipais quanto ao direito de vizinhança e de sossego (SILVA; SIMINI, 2017), permitindo, portanto, que a intensidade do som possa causar incômodo em favor da liberdade religiosa.

Essas garantias exigidas já vêm sendo realizadas no decorrer do século XX, ou seja, uma progressiva desregulação jurídica do Estado da vida religiosa e, consequentemente, a diminuição do controle do governo sobre as ações confessionais, assim como "a liberalização geral da economia das crenças religiosas" (PIERUCCI, 2012, p. 90). Com base na organização e estruturação que podemos observar em várias instituições religiosas no Brasil, notamos que o processo de laicidade, ao mesmo tempo em que busca afastar do aparato estatal o âmbito religioso, permite, por meio do viés da ampla liberdade religiosa, que as diferentes confissões se articulem e passem a atuar com considerável vitalidade no campo sociocultural e político (PIERUCCI, 2012). 
Religare, ISSN: 19826605, v.15, n.2, dezembro de 2018, p.422-450.

\subsection{A Liberdade religiosa pelo protagonismo da família na educação pública}

O protagonismo da família na educação fica explícito na proposição que pretende implantar uma Política Estadual de Liberdade Religiosa. Há uma seção específica para os direitos da criança e do adolescente, onde se estabelece que "os pais ou os responsáveis legais [...] têm o direito de organizar sua vida familiar conforme sua religião, e têm o direito de educar os filhos em coerência com as próprias convicções em matéria religiosa" (Projeto de Lei n. 676/2017, art. 12). Este trecho do projeto de lei guarda semelhança com as aspirações do Movimento Escola Sem Partido, por garantir o direito dos pais educarem religiosamente seus filhos sem nenhum incômodo e intromissão do Estado.

No que tange à liberdade religiosa, a proposta do Escola Sem Partido prevê que o professor respeite a religião dos pais, e pró́be a veiculação de ideias de cunho religioso ou moral que possam estar em desacordo com os princípios dos responsáveis pelos estudantes, ou ainda, aquelas que possam constranger a religiosidade dos alunos. Nesse sentido, o artigo $3^{\underline{0}}$ do projeto de lei aponta para proteção da liberdade de consciência e de crença, e o artigo $4^{\circ}$ para o direito dos pais de educarem moralmente os filhos. Os dois pontos são justificados com a consideração de que a moral é regra inseparável da religião (Projeto de Lei n. 606/2016).

Ao passo que outras proposições buscam fomentar a presença da religião nos diferentes espaços públicos, o Programa Escola Sem Partido gera o impedimento da realização de discussões críticas na escola, ao cercear a liberdade do trabalho docente em prol de um ensino apregoado como ideologicamente neutro. Nessa concepção, entende-se a figura do professor como um doutrinador em potencial, e perde-se a noção de que a educação 
Religare, ISSN: 19826605, v.15, n.2, dezembro de 2018, p.422-450.

acontece nos mais diversos ambientes vivenciados pelo indivíduo, pois "o estudante é educado pela interação da aprendizagem nestes ambientes, constrói suas perspectivas e ideias a partir destas vivências, não sendo mero receptor das informações transmitidas durante a atividade docente" (SILVA; FERREIRA; VIEIRA, 2017, p. 57), como coloca o movimento Escola Sem Partido.

Para entendermos a proposta do Escola Sem Partido, recorremos à fala de Miguel Nagib, líder do Movimento, em debate realizado no programa Expressão Nacional ${ }^{19}$ da TV Câmara, quando contraditou a Procuradora Federal dos Direitos Humanos, Débora Duprat. A mesma questionou sobre a impossibilidade de que o professor atenda às convicções religiosas de cada um dos alunos em sala de aula, especialmente no contexto brasileiro de pluralidade religiosa. Além disso, Duprat trouxe à baila a problemática gerada pela defesa do poder absoluto da família sobre a criança. Miguel Nagib respondeu que a Procuradora estava defendendo a liberdade do professor transmitir suas próprias convicções e crenças aos alunos, e, portanto, doutriná-los: "nenhum país do mundo, talvez a Coreia do Norte, adote esse sistema" (NAGIB, 2017, Youtube).

No bojo dessas discussões, encontramos o pedido de informações ao Secretário de Estado da Educação do Paraná, Fernando Xavier Ferreira, acerca do Plano Estadual de Educação. Na matéria, o Deputado Gilson de Souza questionou quais os grupos participariam dessa discussão de interesse da família paranaense, da qual ele se considera representante (Requerimento $\mathrm{n}$.

\footnotetext{
19 Segundo o site da Câmara dos Deputados: “O Expressão Nacional aborda os grandes temas brasileiros. Representantes do governo Federal, da sociedade civil organizada e deputados debatem ao vivo e de forma aprofundada assuntos como economia, política externa, meio ambiente e tecnologia, entre outros. Opiniões que podem influenciar a tramitação dos projetos enviados ao Congresso Nacional". Informações disponíveis em: $<$ http://www2.camara.leg.br/camaranoticias/tv/programa/36-EXPRESSAO-NACIONAL.html>. Acesso em: 10 out. 2018. A edição em questão está disponível em: $<$ https://www.youtube.com/watch?v=233e1REG3oU>. Acesso em: 20 jul. 2018.
} 
Religare, ISSN: 19826605, v.15, n.2, dezembro de 2018, p.422-450.

1920/2015). Como resultado deste e de outros movimentos, a palavra gênero foi suprimida do Plano Estadual de Educação e substituída pelos termos “igualdade entre homem e mulher" (Lei Sancionada n. 18492/2015) para, segundo a Deputada Claudia Pereira (PSC), evangélica vinculada à Congregação Crista no Brasil, assegurar a autoridade da família numa questão que ultrapassa a religião ${ }^{20}$.

Portanto, para se garantir a liberdade religiosa pelo protagonismo da família, os deputados consideram acertadas as intervenções no ensino público. Essas colocações evidenciam a confecção de uma elevação moral, e até sacralização da família (ALMEIDA, 2017a) como a entidade capaz de controlar todo o processo educativo e de melhor preparar a criança para o convívio social. Diante disso, é possível o questionamento sobre a preocupação dos parlamentares quanto à importância de o sujeito em formação ter contato com o contraditório e a pluralidade de ideias, pois a obrigação de que se leve sempre em consideração a crença, jamais a contrariando, potencialmente gera ocultamentos e silenciamentos de temas em sala de aula, como já vem sendo sugerido pelos movimentos que buscam coibir as discussões de gênero.

\subsection{A liberdade religiosa em detrimento da liberdade de expressão}

Dentre os aspectos já observados nas proposições, outro tema de destaque é a liberdade de expressão da pessoa humana, potencialmente afetada pela iniciativa dos parlamentares evangélicos. A questão mais premente neste domínio é encontrada no projeto que versa sobre a Política

\footnotetext{
${ }^{20}$ A Deputada Claudia Pereira se manifestou a favor dos Deputados Gilson de Souza, Evandro Araújo, Cantora Mara Lima e Pastor Edson Praczyk, entre outros Deputados que defendem a Família, com a justificativa de que estes colaboraram para o trabalho feito a muitas mãos, e resultou na retirada das questões de gênero do plano. Informações disponíveis em: $<$ https://www.youtube.com/watch?v=sCPYrb1R8QM/>. Acesso em: 03 out. 2018.
} 
Religare, ISSN: 19826605, v.15, n.2, dezembro de 2018, p.422-450.

Estadual da Liberdade Religiosa, onde se aborda a questão das violações à liberdade religiosa e as sanções previstas para os atos de intolerância (Projeto de Lei n. 676/2015, capítulo IV). Este trecho abrange os atos discriminatórios, intolerantes, excludentes e violentos decorrentes da divergência de crenças. Para os praticantes desses crimes, a proposição prevê sanções como advertência e multa, para pessoas físicas, e suspensão de licença para exercer suas atividades, para os casos de pessoa jurídica, sem prejuízos para as normas já previstas no Código Penal.

Verifica-se, no entanto, que o projeto não elucida o que seriam estes atos discriminatórios e intolerantes, e deixa aberta a possibilidade para interpretação de que quaisquer críticas dirigidas à religião possam ser passíveis de punição. Desta forma, a liberdade de expressão dos indivíduos, também garantida na Constituição Federal brasileira, passa a ser cerceada em favor da liberdade religiosa.

Notamos ainda que o rigoroso combate à intolerância apresentado no projeto, mesmo sendo proposto por uma Deputada evangélica, pode ser aplicado a outros segmentos religiosos, principalmente às religiões de matriz africana, que foram ao longo da história do Brasil, e ainda são na atualidade, os maiores alvos de ataques discriminatórios. Conforme destacado por Ari Pedro Oro (2012), esta liberdade almejada por alguns grupos evangélicos apresenta um paradoxo quando se trata de algumas religiões evangélicas, visto que as mesmas travam uma verdadeira "guerra espiritual" contra as religiões afro-brasileiras, elencando a "batalha" como um ato de fé e, ao mesmo tempo, desrespeitam as práticas de rituais desses segmentos religiosos. Ou seja, em alguns casos, exigem a liberdade religiosa para si, mas não concordam que outros grupos também desfrutem deste mesmo direito.

Seguindo a mesma linha argumentativa de limitação da liberdade de expressão no projeto que busca instituir o Programa Escola Sem Partido, 
Religare, ISSN: 19826605, v.15, n.2, dezembro de 2018, p.422-450.

temos a liberdade do professor sendo reduzida, ou totalmente restringida ao conteúdo instrumental de cada matéria escolar. Miguel Nagib (2017, Youtube), ao se referir ao Programa, defende a proposta argumentando que: "sempre que você se dirige a uma audiência cativa, você não pode exercer em plenitude a sua liberdade de expressão" ${ }^{21}$. Este posicionamento em defesa do projeto deixa claro que a liberdade de expressão é secundarizada frente à suposta neutralidade ideológica e de crenças, na qual o professor deve se submeter perante a "audiência cativa" que são os alunos. Nagib (2017) ainda afirma que o professor não deve ter liberdade de expressão, pois entende que a mesma daria espaço para que o docente utilizasse o tempo da aula falando da sua vida privada, visto que a presença dos estudantes é obrigatória em sala de aula.

Ainda no que tange ao cerceamento das liberdades, notamos que, no requerimento de moção de repúdio à peça teatral Pornô Gospel, a liberdade religiosa é apresentada como soberana em relação à liberdade de expressão artística. Como justificativa para a proposição, os deputados argumentam a incontestável liberdade religiosa como direito de todos,

[...], portanto, nenhum indivíduo ou grupo religioso, majoritário ou minoritário, pode ser objeto de discriminação por motivos de religião ou crenças por parte do Estado, de qualquer instituição, grupos de pessoas ou particulares. (Requerimento n. 3.024/2016).

Nesse sentido, os deputados evangélicos solicitam informações à Secretaria de Estado da Cultura, questionando se havia financiamento público para a produção da peça e sobre as condições para a concessão do Teatro Guaíra - instituição cultural em Curitiba, mantida pelo Governo do Estado -, palco da exibição do espetáculo (Requerimento n. 2939/2016). Essa

\footnotetext{
${ }^{21}$ Esse discurso é encontrado em entrevista concedida em 2017 ao Canal Dois Dedos de Teologia, na Plataforma Youtube, em vídeo disponível em: <https://www.youtube.com/watch?v=sgXDz9gpng\&t=671sl>. Acesso em: 3 out. 2018.
} 
Religare, ISSN: 19826605, v.15, n.2, dezembro de 2018, p.422-450.

ação é uma medida distante daquela direcionada para as organizações religiosas na Política Pública de Liberdade Religiosa e na proposição do Dia Estadual de Proclamação do Evangelho, porque nesses projetos, a parceria das religiões com o poder público é protegida para garantir a livre expressão do discurso religioso (Projeto de Lei n. 676/2015, art. 8, Parágrafo único; Projeto de Lei n. 675/2017).

A peça teatral, ao satirizar a atuação dos líderes religiosos, parece atingir a aura sacra que os mesmos arrogam para si, porquanto se colocam como homens e mulheres de Deus na política e reserva moral da sociedade (CARRANZA, 2017; DUARTE, 2012). Isso se torna relevante porque na postura para fora do templo religioso, os evangélicos vêm adotando nos discursos e em suas práticas

[...] uma forma de sacralização dos seus agentes e dos seus instrumentos. A aura divina passou a habitar os muitos domínios sociais que, por sua vez, passaram a fornecer a matéria-prima necessária para forjar o protagonismo divino dos pastores. (BIRMAN, 2012, p. 137).

Os deputados consideram que a liberdade religiosa, contra uma presumida ofensa praticada pelo meio artístico, deve ser defendida em detrimento da liberdade de expressão. Um sentido corporativista atua instrumentalizando a produção legislativa por meio da união dos parlamentares para proteger a moral dos líderes evangélicos e o espaço das igrejas. Portanto, a partir dessa posição argumentativa, faz sentido protestar e punir o suposto desrespeito ante ao religioso que pode vir dos professores, dos artistas, ou de qualquer pessoa física ou jurídica.

\section{Conclusão}

Ao investigarmos o modo como a liberdade religiosa é pautada pelos deputados evangélicos na ALEP, buscamos discutir como são acionadas as 
Religare, ISSN: 19826605, v.15, n.2, dezembro de 2018, p.422-450.

justificativas para se legislar em torno do direito à liberdade das igrejas e à manifestação das crenças. Pudemos evidenciar o constante embasamento na Constituição Federal, e nesse sentido os modos pelos quais os deputados vinculados à igrejas evangélicas, implícita ou explicitamente, manifestam os valores cultuados por seus grupos. Desta forma, os políticos religiosos buscam marcar espaço na cena pública, e incluir tais denominações religiosas como constituintes legítimas da cultura brasileira.

As oito proposições aqui estudadas, tanto os projetos de lei como os requerimentos, permitem verificar uma das formas dos evangélicos se inserirem na cultura nacional, tornando manifestos seus valores e crenças. A via política se tornou para alguns grupos religiosos um campo de intensas disputas por poder e legitimação social. Nesse âmbito, assegurar o direito à liberdade religiosa implica não somente a liberdade de crença e de culto, mas também em garantir espaços para reconfigurar o cenário público nacional e, consequentemente, formar uma cultura pública evangélica (GIUMBELLI, 2014).

A análise do material empírico corrobora com a constatação de que estes políticos religiosos estão presentes e ativos na política estadual. Podemos notar que os interesses dos deputados evangélicos apresentam convergências, e formam o que podemos considerar uma Bancada Evangélica na ALEP. Os três eixos argumentativos que identificamos nas proposições a não intervenção do Estado na atividade religiosa, o protagonismo da família ante a educação pública, e a liberdade religiosa em detrimento da liberdade de expressão - demonstram uma certa articulação entre esses parlamentares. Notamos também que os políticos se apresentam como conservadores no campo da moral, utilizando o discurso da liberdade religiosa contra a liberdade de expressão, contra a discussão das questões de gênero e em defesa do poder da família sobre a educação. 
Religare, ISSN: 19826605, v.15, n.2, dezembro de 2018, p.422-450.

A forma de atuação destes deputados e a presença de elementos religiosos no âmbito político são defendidas tendo como fundamento o ideal de laicidade do Estado, que dá origem ao princípio da liberdade religiosa. $\mathrm{O}$ acionamento do discurso sobre a liberdade religiosa pode ser amplamente verificado nas proposições analisadas. Este é um fator que também demonstra a adequação dos argumentos dos religiosos a um discurso juridicamente aceito, em que não há a inserção de justificativas que demonstrem parcialidades de crenças ou devoção, mas sim neutralidade devocional e até uma defesa da pluralidade.

Neste cenário, o foco agora não é mais verificar a autonomia do Estado frente ao âmbito religioso ou o grau de privatização das instituições devocionais, mas entender como os atores religiosos se fazem presentes na esfera pública e demarcam o território daqueles que representam (GIUMBELLI, 2014). As relações estabelecidas entre religião, política e espaço público trazem outra dinâmica para a sociedade, atingindo as formas de interação entre indivíduo e meio social, e gerando reflexões sobre o futuro da política e da cultura nacional.

\section{Referências}

ALMEIDA, Ronaldo. A onda quebrada - evangélicos e conservadorismo. Cadernos Pagu, Campinas, n. 50, p. 1-27, jun. 2017a.

ALMEIDA, Ronaldo. Os deuses do Parlamento. Novos Estudos, São Paulo, Edição Especial, p. 71-79, jun. 2017b.

ARAGÃO, Jarbas. Peça teatral "Pornô Gospel" satiriza pastores e cantores. Gospelprime, 3 de jun. 2016. Disponível em: <https://noticias.gospelprime.com.br/peca-porno-gospel-satiriza-pastores/> Acesso em: 10 out. 2018.

BIRMAN, Patricia. O poder da fé, o milagre do poder: mediadores evangélicos e deslocamento de fronteiras sociais. Horizontes Antropológicos, Porto Alegre, vol. 18, n. 37, p. 133-153, jan./jun. 2012.

BÍBLIA SAGRADA. 4 ed. Barueri: Sociedade Bíblica do Brasil, 2009.

BRASIL. Constituição da República Federativa do Brasil. Brasília: Supremo Tribunal Federal, Secretaria de Documentação, 2018. Disponível 
Religare, ISSN: 19826605, v.15, n.2, dezembro de 2018, p.422-450.

em:<http://www.stf.jus.br/arquivo/cms/legislacaoConstituicao/anexo/CF.pd $>$ Acesso em: 10 out. 2018.

BURITY, Joanildo. A cena da religião pública: Contingência, dispersão e dinâmica relacional. Novos Estudos CEBRAP, São Paulo, vol. 102, p. 93-109, 2015.

. A onda conservadora na política brasileira traz o fundamentalismo ao poder? In: ALMEIDA, Ronaldo de; TONIOL, Rodrigo (Orgs). Conservadorismo, fascismos e fundamentalismo: análises conjunturais. Campinas: Editora da Unicamp, 2018, p. 15-66.

BURITY, Joanildo. Religião, cultura e espaço público: onde estamos na presente conjuntura? In: MEZZOMO, Frank Antonio; PÁTARO, Cristina Satiê de Oliveira; HAHN, Fábio André (Orgs.). Religião, Cultura e Espaço público. São Paulo: Olho D’Água; Campo Mourão: Fecilcam, 2016, p. 13-49.

CAMURÇA, Marcelo Ayres. A questão da laicidade no Brasil: mosaico de configurações e arena de controvérsias. Horizonte, Belo Horizonte, vol. 15, n. 47, jul./set. 2017.

CARRANZA, Brenda. Modus Operandi político de evangélicos e católicos: consolidações e inflexões. Debates do NER, Porto Alegre, ano 18, n. 32, p. 87116, jul./dez. 2017.

CARVALHO, Ivo César Barreto de. Imunidade Tributária na Visão do STF. Direito Público, Brasília, vol. 8, n. 33, p. 68,86, maio/jun. 2011.

CARVALHO JUNIOR, Erico Tavares de; ORO, Ari Pedro. Eleições municipais 2016: religião e política nas capitais brasileiras. Debates do NER, Porto Alegre, ano 18, n. 32, p. 15-68, jul./dez. 2017.

CRESPI, Carlos; KEMPFER Marlene. Uma noção de "Templos de Qualquer Culto" para os fins do Artigo 150, VI, "B" da Constituição. Scientia Iuris, Londrina, vol. 17, n. 1, p. 91-106, jul. 2013.

CUNHA, Christina Vital da; LOPES, Paulo Victor Leite; LUI, Janayna. Religião e Política: medos sociais, extremismo religioso e as eleições 2014. Rio de Janeiro: Fundação Heinrich Böll e Instituto de Estudos da Religião, 2017.

DUARTE, Tatiane dos Santos. A participação da frente parlamentar evangélica no legislativo brasileiro: ação política e (in) vocação religiosa. Ciências Sociais e Religião, Porto Alegre, ano 14, n. 17, p. 53-76, jul./dez. 2012.

ESCOLA SEM PARTIDO. Escola sem partido: educação sem doutrinação. Disponivel em: <http://www.escolasempartido.org/objetivos>. Acesso em: 10 out. 2018.

Expressão Nacional, Tv Câmara. Você já ouviu falar na "Escola sem Partido"?. Disponível em: <https://www.youtube.com/watch?v=233e1REG3oU>. Acesso em: 10 out. 2018.

GIUMBELLI, Emerson. O que é um ambiente laico? Espaços (inter)religiosos em instituições públicas. Cultura Y Religión, Santiago, vol. 7, n. 2, p. 32-47, jun./dez. 2013. 
Religare, ISSN: 19826605, v.15, n.2, dezembro de 2018, p.422-450.

. Cultura pública: evangélicos e sua presença na sociedade brasileira. In: GIUMBELLI, Emerson. Símbolos Religiosos em Controvérsias. São Paulo: Terceiro Nome, 2014, p. 189-208.

HERVIEU-LÉGER, Danièle. O peregrino e o convertido: a religião em movimento. 2aㅡ ed. Petrópolis: Vozes, 2015.

IBGE. Censo demográfico 2010. Disponível em: $<$ https://censo2010.ibge.gov.br/noticiascenso?id=3\&idnoticia=2170\&view=no ticia>. Acesso em: 10 out. 2018.

LEITE, Fábio Carvalho. Liberdade religiosa e objeção de consciência: o problema do respeito aos dias de guarda. In: ORO, Ari Pedro et al. (Orgs.). A religião no espaço público: atores e objetos. São Paulo: Terceiro Nome, 2012, p. 157-179.

. Estado e religião: a liberdade religiosa no Brasil. Curitiba: Juruá Editora, 2014.

MARIANO, Ricardo. Pentecostais e política no Brasil: do apolitismo ao ativismo corporativista. In. SANTOS, Hermílio. Debates pertinentes: para entender a sociedade contemporânea. Porto Alegre: EDIPUCRS, 2009, p. 112-138.

. Laicidade à brasileira: católicos, pentecostais e laicos em disputa na esfera pública. Civitas, Porto Alegre, vol. 11, n. 2, p. 238-258, maio/ago. 2011. MEYER, Birgit. Mediação e Imediatismo: formas sensoriais, ideologias semióticas e a questão do meio. Campos: Revista de Antropologia, Curitiba, vol. 16, n. 2, 145-164, 2015.

MIRANDA, Júlia. E o laico no Brasil: entre sofismas e ambiguidades. Revista Cultura y Religión, Santiago, vol. 7, n. 2, p. 69-85 jun./dez. 2013.

MONTERO, Paula. Religião, pluralismo e esfera pública no Brasil. Novos Estudos, São Paulo, n. 74, p. 47-65, mar. 2006.

- Controvérsias religiosas e esfera pública: repensando as religiões como discurso. Religião e Sociedade, Rio de Janeiro, vol. 32, n. 1, p. 167-183, 2012. MOSER, Sandro. Vereadores de Curitiba repudiam a peça teatral "Pornô Gospel". Gazeta do Povo, 31 de maio de 2016. Disponível em: $<$ https://www.gazetadopovo.com.br/caderno-g/teatro/vereadoresdecuritibarepudiam-a-peca-teatralpornogospel0tpc0xhypff7yyh5vb7p3z80s/>. Acesso em: 10 out. 2018.

NAGIB, Miguel. Miguel Nagib responde os cristãos sobre o escola sem partido. 7 de ago. 2017. Disponível em: <https://www.youtube.com/watch? $\mathrm{v}=\mathrm{sgX}$ Dz9gpng\& $\mathrm{t}=671 \mathrm{sl}>$. Acesso em: 10 out. 2018.

NASCIMENTO, Guilherme Martins; DUARTE, Evandro Piza; QUEIROZ, Marcos Vinícius Lustosa. O silêncio dos juristas: a imunidade tributária sobre templo de qualquer culto e as religiões de matriz africana à luz da constituição de 1988. Quaestio Iuris, Rio de Janeiro, vol. 10, n. 2, p. 1162-1180, 2017. 
Religare, ISSN: 19826605, v.15, n.2, dezembro de 2018, p.422-450.

ORO, Ari Pedro. Liberdade religiosa no Brasil: as percepções dos atores sociais. In: ORO, Ari Pedro et al. (Orgs.). A religião no espaço público: atores e objetos. São Paulo: Terceiro Nome, 2012, p. 181-193.

PARANÁ. Regimento Interno da Assembleia Legislativa do Estado do Paraná. Curitiba: Assembleia Legislativa do Estado do Paraná, Curitiba, 2016. Disponível em: <http://www.ALEP.pr.gov.br/legislacao/regimento_interno>. Acesso em: 10 out. 2018.

PIERUCCI, Antônio Flávio. O crescimento da liberdade religiosa e o declínio da religião tradicional: a propósito do censo 2010. ANUAC, Cagliari, vol. 1, n. 2, p. 87-96, nov. 2012.

RANQUETAT JÚNIOR, Cesar Alberto. A presença da Bíblia e do crucifixo em espaços públicos no Brasil: religião, cultura e nação. In: ORO, Ari Pedro et al. (Orgs.). A religião no espaço público: atores e objetos. São Paulo: Terceiro Nome, 2012, p. 45-79.

ROSA, Daiana Nunes da; MEZZOMO, Frank Antonio; PÁTARO, Cristina Satiê de Oliveira. Agentes religiosos em campanha eleitoral para a Assembleia Legislativa do Paraná. Anais do VI Colóquio Nacional Cultura e Poder. Campo Mourão, vol. 5, p. 189-203, 2017.

SILVA, Alexandre Fernando da; FERREIRA, José Heleno; VIEIRA, Alexandre. O discurso falacioso do Movimento Escola Sem Partido. Revista Pedagógica, Chapecó, vol. 19, n. 42, p. 49-65, set./dez. 2017.

SILVA, Leonardo dos Santos; SIMINI, Danilo Garnica. Liberdade de culto e seus eventuais excessos: o exemplo da cidade de Ituverava/SP. Revista Eletrônica Direito e Política, Itajaí, vol. 12, n. 3, p. 1568-1589, set./dez. 2017.

SILVA, Rogério Duarte da. As imunidades tributárias - natureza a partir da Constituição Federal de 1988 e sua interpretação judicial. 158f. Dissertação (Mestrado em Direito). Universidade Federal de Santa Catarina, Florianópolis, 2002.

TERAOKA, Thiago Massao Cortizo. A liberdade religiosa no direito constitucional brasileiro. 282f. Tese (Departamento de Direito do Estado da Faculdade de Direito). Universidade de São Paulo, São Paulo, 2010.

VITAL, Christina; LOPES, Paulo Victor Leite. Religião e política: uma análise da atuação de parlamentares evangélicos sobre direitos das mulheres e de LGBTs no Brasil. Rio de Janeiro: Fundação Heinrich Böll, 2012.

Recebido em 16-09-2018. Aprovado em 20-01-2019. 